\title{
PROSES PERUBAHAN DIRI SEORANG TERORIS MENJADI AKTIVIS PERDAMAIAN
}

\author{
Muhammad Syafiq \\ Program Studi Psikologi Universitas Negeri Surabaya \\ Sur-el : muhammadsyafiq@unesa.ac.id
}

\begin{abstract}
This qualitative study was aimed at exploring the experience of a former member of a terrorist organization in Indonesia who have left his terrorist group and abandoned the extremist ideology. A life history method which focuses on the process of self-change and life transition of the former member of the terrorist group was employed A participant whose age is 40 years old and was a former active member of Jamaah Islamiyah (JI), a terrorist group, was recruited. He was captured in 2014 and served a sentence in prison for almost 4 years. He has been involved in counterterrorism campaign organized by a non-government organization (NGO) since his release from prison until recently. Interviews were conducted to collect data which were then analyzed using a narrative analysis. Some written documents in the forms of articles and a published book produced by the participant as well as online news covering the participant' stories were also examined. The findings inform how he became involved in the terrorist networks. The need for self-significance and adventurous experience seems to be the main drivers. After his capture, and during his imprisonment, he contemplated his participation in the terrorist networks. His meetings with religious experts and academicians facilitated by prison officers, and his awareness of burden he had inflicted on his family because of his terrorism case had opened his mind. He experienced a turning life moment which made him keeping distance from other terrorist inmates with the risk of receiving negative view from them. After his release, he found passion in writing and eventually reached a NGO and joined it as a credible voice in the campaigns of counter violent extremism through writing and public speaking.
\end{abstract}

Keywords: self-change, deradicalization, disengagement, terrorism

\begin{abstract}
Abstrak : Penelitian kualitatif ini bertujuan untuk mengeksplorasi pengalaman mantan anggota organisasi teroris di Indonesia yang telah meninggalkan kelompok teroris dan menolak ideologi ekstremnya. Metode life history digunakan dengan fokus pada proses perubahan diri dan transisi hidupnya. Seorang partisipan yang berusia 40 tahun dan merupakan mantan anggota aktif Jamaah Islamiyah (JI), sebuah kelompok teroris, berhasil direkrut. Dia ditangkap pada tahun 2014 dan menjalani hukuman penjara selama hampir 4 tahun. Dia telah terlibat dalam kampanye kontra-terorisme yang diselenggarakan oleh organisasi non-pemerintah sejak dibebaskan dari penjara hingga saat ini. Wawancara dilakukan untuk mengumpulkan data yang kemudian dianalisis menggunakan analisis naratif. Beberapa dokumen berupa artikel dan buku yang ditulis oleh partisipan serta berita online yang meliput kisah partisipan juga dikaji. Temuan penelitian ini menginformasikan bagaimana partisipan terlibat dalam organisasi teroris. Kebutuhan akan arti diri dan pengalaman berpetualang sebagai anak muda tampaknya menjadi pendorong utama. Setelah penangkapannya, dan selama dipenjara, ia berkesempatan untuk mengevaluasi kembali partisipasinya dalam jaringan teroris. Pertemuan dengan para ahli agama dan akademisi yang difasilitasi oleh petugas, dan kesadarannya akan beban yang ia sebabkan pada keluarganya karena kasus terorismenya telah membuka hatinya. Ia mengalami momen hidup yang berubah yang membuatnya menjaga jarak dengan narapidana teroris lainnya dengan risiko menerima pandangan negatif dari mereka. Setelah dibebaskan, ia sudah memiliki jaringan alternatif melalui para ahli agama dan akademisi yang mengunjunginya di penjara dan menemukan gairah dalam menulis. Dia akhirnya mencapai sebuah organisasi non-
\end{abstract}


pemerintah dan bergabung sebagai agen kampanye kontra ekstremisme kekerasan melalui tulisan dan ceramah di depan publik.

Kata kunci: perubahan diri, deradikalisasi, disengagement, terorisme

\section{PENDAHULUAN}

Penelitian tentang perubahan diri dari seorang yang terlibat dalam jaringan terorisme menjadi individu yang menolak ideologi terorisme dan kekerasan, atau disebut juga deradikalisasi, masih diperlukan hingga saat ini (Koehler, 2017; Horgan \& Altier, 2012; Rabasa dkk., 2010). Dibandingkan dengan penelitian tentang proses radikalisasi, topik deradikalisasi masih tergolong lebih sedikit (Schmid, 2013). Para peneliti dan pengambil kebijakan cenderung lebih fokus pada mereka yang masih aktif dalam jaringan teorisme atau yang rentan terpapar ideologi terorisme karena potensi ancamannya yang nyata. Mereka yang pernah terlibat dan akhirnya berhenti dari jaringan terorisme dipandang bukan lagi menjadi ancaman (Horgan \& Braddock, 2010). Pada kenyataannya, salah satu isu penting yang perlu dipertimbangkan dalam pencegahan terorisme adalah wawasan tentang bagaimana dan mengapa para radikal atau teroris bergabung dalam, dan akhirnya meninggalkan, kelompok dan ideologi terorisme (Scmidt, 2013; Rabasa dkk., 2010). Berdasarkan data Badan Nasional Penanggulangan Terorisme (BNPT), hingga tahun 2018 terdapat 289 narapidana kasus terorisme yang menjalani hukuman di 113 Lembaga pemasayarakatan di seluruh Indonesia (Kompas.com, 2018). Angka ini menurun cukup signifikan dalam sepuluh tahun terakhir. Yayasan Prasasti Perdamaian menyebutkan bahwa jumlah populasi narapidana teroris di Indonesia dari 2002 hingga 2011 mencapai sekitar 600 orang (Andrie, 2011). Mereka dihukum di berbagai Lapas di Indonesia dengan lama antara 7-20 tahun, serta beberapa mendapatkan hukuman seumur hidup. Sejumlah 245 orang telah dibebaskan melalui pembebasan bersyarat (PB) sepanjang tahun 2006-2010. Dari mereka yang dibebaskan tersebut terdapat 18 orang yang kembali terlibat dalam aksi terorisme sepanjang tahun 2009-2010 (Andrie, 2011). Pada tahun 2020, jumlah narapidana kasus terorisme tercatat 524 narapidana yang menjalani hukuman di 88 Lapas di Indonesia, dimana 13 orang diantaranya adalah wanita (Badan Pembinaan Hukum Nasional, 2020). Angka ini menunjukkan peningkatan dibandingkan jumlah narapidana teroris pada tahun 2018. 
Meskipun jumlah populasi napi terorisme yang masih dalam tahanan maupun yang sudah dibebaskan tidak terlalu besar dibanding populasi seluruh penduduk Indonesia, namun tingkat ancaman dan dampak kerusakan yang ditimbulkan akan cukup signifikan seandainya mereka kembali pada aksi terorisme. Karena itu diperlukan berbagai penelitian untuk memahami kondisi psikologis pada mantan pelaku terorisme yang telah menjalani proses deradikalisasi untuk memberi wawasan pada para pemangku kebijakan agar berbagai program rehabilitasi dan deradikalisasi menjadi lebih efektif (Cherney, 2018; Hettiarachchi, 2018).

Proses deradikalisasi dapat melibatkan perubahan dalam ranah kognitif, afektif, dan perilaku seorang yang radikal menuju kearah yang lebih moderat (Clubb, 2014). Keseluruhan aspek yang terlibat dalam proses deradikalisasi ini, karena itu, akan terkait dengan proses psikologis. Dalam upaya memahami proses deradikalisasi ini, yaitu perubahan diri dari yang semula radikal ekstrem menjadi moderat, maka perlu terlebih dahulu memahami tentang radikalisasi. Maculey dan Maskolenko (2008, hal. 416) menjelaskan bahwa radikalisasi adalah 'perubahan keyakinan (beliefs), perasaan (feelings), dan perilaku (behaviors) ke arah yang semakin menjustifikasi kekerasan antar kelompok dan pengorbanan dalam membela kelompok sendiri (in-group)'. Fungsi radikalisasi, menurut mereka, adalah mengintensifkan kesiapan dan komitmen untuk konflik antar kelompok. Mereka membedakan 'radikalisme' dari 'aktivisme,' di mana istilah pertama didefinisikan sebagai kesiapan untuk terlibat dalam aksi politik ilegal dan kekerasan, sementara istilah yang terakhir didefinisikan sebagai kesiapan untuk terlibat dalam aksi politik secara legal dan bersifat non-kekerasan' (Maculey \& Maskolenko, 2009).

Horgan (2009) membedakan radikalisasi dengan 'radikalisasi kekerasan'. Dia mendefinisikan radikalisasi sebagai: "proses sosial dan psikologis dari komitmen bertahap terhadap ideologi politik atau agama yang ekstrem. Radikalisasi mungkin tidak selalu mengarah pada kekerasan, namun adalah salah satu dari beberapa faktor risiko yang diperlukan untuk munculnya kekerasan". Sementara 'radikalisasi kekerasan' adalah: "Proses sosial dan psikologis dari radikalisasi yang meningkat dan terfokus pada keterlibatan dengan gerakan kekerasan non-negara'. Meskipun radikalisasi tidak selalu melibatkan tindakan kekerasan, dalam konteks terorisme, istilah ini mengacu ke 'radikalisasi kekerasan' versi Horgan (2009). Oleh karena itu, arti deradikalisasi di sini perlu dilihat sebagai sebuah gerakan kognitif, psikologis atau fisik untuk meninggalkan suatu kelompok ekstrem 
yang menghalalkan cara kekerasan atas nama agama (Islam) untuk mencapai tujuan ideologis mereka.

Horgan (2009) juga membedakan antara 'deradikalisasi' dengan 'disengagement'. Menurutnya, deradikalisasi mengacu pada perubahan dalam pemikiran atau kepercayaan dari memeluk ideologi radikal kekerasan menjadi menolaknya. Sementara disengagement berhubungan dengan perubahan perilaku yang signifikan untuk menghindari dan menolak berpartisipasi dalam aksi kekerasan. Dengan demikian, proses deradikalisasi berada di level kognitif berkaitan dengan perubahan dalam komitmen ideologi. Sedangkan disengagement berada di tingkat perilaku berkaitan dengan penolakan untuk berpartisipasi dalam aksi kekerasan atas nama ideologi kekerasan. Horgan menegaskan bahwa perbedaan antara dua istilah tersebut penting untuk memahami kenyataan bahwa tidak semua individu yang telah meninggalkan terorisme (disengaged) juga meninggalkan ideologi kelompok teroris (deradicalised).

Proses deradikalisasi dan disengagement sering dipicu oleh peristiwa penting yang menyebabkan krisis emosional seperti pengalaman mendapat belas kasih dari mereka yang semula dianggap musuh, rasa bersalah pada keluarga sendiri yang dirugikan, kematian dari korban yang tidak bersalah, atau peristiwa lain yang signifikan dan bermakna bagi pelaku (Garfinkel, 2007). Krisis emosional ini seringkali pada akhirnya membuka pikiran orang berpaham ekstrem kekerasan hingga mereka mulai meragukan nilai-nilai dan keyakinan radikal mereka (Bjorgo, 2009). Selanjutnya, keberhasilan dari pemicu itu untuk membuat individu meninggalkan kelompok mereka akan sangat ditentukan oleh kekuatan faktor pendorong (push) dari dalam jaringan sendiri, dan faktor penarik (pull) dari masyarakat luar jaringan. Jika kedua faktor tersebut cukup kuat, individu akan mencapai titik balik dan meninggalkan kelompok ekstrem kekerasan mereka.

Menurut Horgan (2009), yang termasuk faktor pendorong adalah adanya kekecewaan terhadap tujuan, metode, dan pemimpin kelompok, kemudian hubungan sosial dan status mereka serta tekanan yang dialami sebagai anggota gerakan bawah tanah. Sementara faktor penarik yang membuat orang meninggalkan terorisme adalah adanya amnesti atau pengurangan hukuman, pendidikan dan pelatihan, peluang bersifat material, serta peluang membangun jaringan sosial baru di luar kelompok lama termasuk rekan kerja, pertemanan, atau membentuk keluarga (Horgan,2009). Pada tahap selanjutnya, individu yang telah meninggalkan terorisme pelu dapat membangun peran dan identitas baru sebagai warga masyarakat sehingga dapat berreintegrasi ke masyarakat umum (Rabasa dkk., 2010:12). Keberhasilan dalam mendapatkan peran dan identitas baru 
termasuk pekerjaan akan menentukan kelanggengan disengagement dan deradikalisasi.

Dalam kasus penangkapan dan pemenjaraan mereka yang terlibat terorisme, mereka secara otomatis terpaksa berhenti dari jaringan terorisme. Keterpaksaaan ini membuat mereka mungkin berhenti secara fisik (disengaged) dari aksi kekerasan, namun tidak otomatis membuat keyakinan ideologis mereka berubah. Berdasarkan studinya, Horgan (2009) menyatakan bahwa individu yang melepaskan diri dari jaringan terorisme mungkin belum sampai mengalami deradikalisasi, yaitu melepaskan dan menolak ideologi ekstrem yang sebelumnya diyakini. Namun, ia menyatakan bahwa disengagement itu sendiri sudah merupakan indikator yang baik untuk memastikan risiko residivisme yang rendah karena hubungan mereka telah terputus dengan jaringan terorisme.

Penelitian lain menunjukkan bahwa teroris atau radikal, yang tidak lagi percaya pada ideologi kelompok mereka, terkadang masih tinggal di kelompok mereka karena mereka tidak ingin meninggalkan mereka yang sudah dianggap keluarga atau saudara (Noricks, 2009). Norricks (2009) juga mencatat pentingnya faktor afiliatif seperti hubungan pribadi, rasa memiliki, dan jaringan sosial yang menentukan baik partisipasi dalam jaringan terorisme maupun berhentinya seseorang dari jaringan tersebut.

Karena itu, perubahan seorang mantan anggota jaringan terorisme menjadi lebih moderat akan ditentukan oleh motif awal bergabung dalam jaringan terorisme, pengalaman hidup selama berada di dalam, dan berbagai peristiwa baik yang diinginkan atau tidak setelah lepas dari jaringan. Penelitian sebelumnya telah mendukung kesimpulan yang menyatakan bahwa faktor jaringan sosial alternatif yang tersedia adalah salah satu faktor terpenting dalam membuat seorang mantan ekstremis kekerasan bertahan dalam keputusan untuk meninggalkan terorisme (Hwang, 2018; Harris dkk., 2017; Koehler, 2017).

Berdasarkan latar belakang tersebut, penelitian ini bertujuan untuk mengungkap proses disengagement dan deradikalisasi pada seorang mantan anggota jaringan terorisme di Indonesia. Penelitian ini berfokus pada proses perubahan diri partisipan tersebut sejak dari proses bergabung dan aktif dalam jaringan terorisme hingga saat ini berubah menjadi seorang aktivis yang mengkampanyekan kontra-ekstremisme dan perdamaian. Penelitian ini diharapkan dapat memenuhi kebutuhan penting untuk menghasilkan data dari tangan pertama yang akan memberikan wawasan mengenai bagaimana dan mengapa orang berhenti berpartisipasi dalam gerakan dan ideologi ekstrem kekerasan dalam konteks 
masyarakat Indonesia.

\section{METODOLOGI PENELITIAN}

Penelitian ini menggunakan metode life history untuk mengungkap kisah personal seorang mantan anggota jaringan teroris yang saat ini menjadi aktivis sebuah lembaga swadaya masyarakat (LSM) yang mengkampanyekan perdamaian. Metode life history digunakan karena memungkinkan peneliti untuk mengungkap sebuah kisah perjalanan hidup seseorang yang memuat peristiwa-peristiwa penting yang menentukan arah (turning points) dalam kehidupannya dalam suatu periode waktu tertentu (Hagemaster, 1992).

Partisipan penelitian ini adalah seorang mantan anggota jaringan teroris, yaitu Jamaah Islamiyah (JI), yang pernah mendekam dalam penjara. Peneliti mengenal partisipan dari aktivis LSM yang saat ini diikutinya. Setelah melakukan pertemuan beberapa kali, akhirnya partisipan bersedia untuk terlibat dalam penelitian ini. Partisipan dengan nama samaran Raudan ini sekarang berusia menjelang 40 tahun dan telah berkeluarga dan memiliki anak. Ia terlibat dalam JI antara tahun 2002-2014. Pada tahun 2014 itu ia ditangkap di Jakarta dan kemudian di hukum penjara dengan vonis 4 tahun 10 bulan lebih rendah dari tuntutan jaksa selama 7 tahun. Dakwaan yang dikenakan adalah jual beli senjata api.
Setelah menjalani hukuman dan bebas, ia terlibat dalam aktivitas sosial difasilitasi oleh sebuah LSM yang berfokus pada pemberdayaan dan reintegrasi mantan narapidana terorisme. Saat ini, partisipan menjadi salah satu aktivis dalam lembaga tersebut. Selama menjalani hukuman penjara, partisipan mendapatkan kunjungan dari ahli agama, kriminolog, dan psikolog dari perguruan tinggi. Dari perjumpaannya dengan para ahli tersebut, Raudan mulai berpikir tentang kegiatan pribadi yang dapat dilakukannya di dalam penjara. Akhirnya ia memutuskan untuk belajar menulis cerita fiksi dan tulisan non-fiksi terinspirasi dari kisah hidupnya sendiri. Menjelang bebas, Raudan telah memiliki kontak dengan salah satu ahli dari perguruan tinggi tersebut. Setelah bebas Raudan mendapatkan jalur melalui ahli tersebut untuk bertemu dengan beberapa aktivis LSM berbasis di Jakarta yang bergerak dalam program pemberdayaan mantan narapidana kasus terorisme. Ia akhirnya mendapatkan bimbingan dan pelatihan serta kemudian aktif hingga sekarang sebagai credible voice untuk kampanye kontraterorisme di LSM tersebut. Raudan telah menulis beberapa artikel dan telah menerbitkan sebuah buku berdasarkan kisah hidupnya.

Penelitian ini menggunakan wawancara mendalam semi-terstruktur. Wawancara semi terstruktur dipilih karena jenis wawancara ini 
memungkinkan peneliti untuk mengikuti minat dan keinginan partisipan selama wawancara namun tetap menjaga alur wawancara sesuai topik penelitian. Sebelum wawancara dilakukan, peneliti terlebih dahulu melakukan pertemuan awal untuk memperkenalkan diri di sela kegiatan partisipan dalam memberikan seminar bertopik pencegahan terorisme yang dilaksanakan oleh LSM berbasis di Jakarta di mana saat ini partisipan bergabung sebagai anggotanya. Wawancara dilakukan di bagian pojok lobby sebuah hotel di Surabaya menjelang malam ketika sepi selama sekitar 1,5 jam dan direkam menggunakan smartphone. Setelah wawancara ini, peneliti melakukan satu kali pertemuan lagi dengan partisipan di sebuah tempat makan pada situasi sepi di malam hari di sekitar terminal di Sidoarjo, Jawa Timur. Dalam pertemuan ini, peneliti melakukan wawancara informal yang tidak direkam untuk mendalami hasil wawancara sebelumnya. Peneliti mengandalkan ingatan dan melakukan pencatatan tak lama setelah pertemuan selesai. Selain itu, peneliti melakukan komunikasi melalui whatsapp dan voice call terkait aktivitas yang saat ini dijalani oleh partisipan. Beberapa kali peneliti juga mengikuti kegiatan partisipan secara publik dan melakukan perekaman atas materi testimoni perjalanan hidup partisipan yang disampaikan dalam seminar publik. Mengingat partisipan juga telah menulis artikel dan buku perjalanan hidupnya sebagai mantan anggota jaringan teroris, peneliti juga mendapatkan data dari dokumen tulisan artikel di website dan buku cetak karya partisipan.

Data dianalisis menggunakan teknik analisis naratif dengan prosedur pengolahan data yang mengacu pada saran Riessman (1993), yaitu mengidentifikasi tema-tema umum dalam narasi atau cerita subjek, kemudian data penelitian dikategorisasi berdasarkan tema-tema narasi tersebut. Berikutnya, tema-tema umum narasi yang telah berisi data tersebut disusun dalam alur cerita yang paling sesuai. Dalam setiap alur cerita tersebut, kemudian ditonjolkan narasinarasi inti sesuai fokus penelitian.

Dalam upaya untuk menjaga keabsahan data, peneliti telah melakukan beberapa klarifikasi pada partisipan atas data tertentu dari hasil wawancara yang dilakukan sebelumnya. Selain itu, data hasil wawancara, dibandingkan oleh peneliti dengan tulisantulisan partisipan baik dalam bentuk artikel maupun buku yang ditulisnya, serta beritaberita reportase tentang partisipan yang telah dipublikasikan media massa online.

\section{HASIL DAN PEMBAHASAN}

Hasil penelitian ini distrukturkan dalam 3 tema kisah utama beralur kronologis, yaitu: terbakar semangat berjihad, terbukanya pikiran, dan menjadi aktivis perdamaian. 


\section{Terbakar semangat berjihad}

Raudan menjalani pendidikan di lingkaran para guru agama yang menjadi simpatisan dan sebagian menjadi kader Jamaah Islamiyah (JI), kelompok teroris pelaku Bom Bali 1 pada 12 Oktober 2002. Ia menempuh pendidikan sekolah menengah pertama di pondok pesantren tempat para guru agama tersebut. Alasan memilih studi ke pondok pesantren itu karena para guru agama yang mengelolanya masih kerabat dekat dari pihak ibunya.

Kalau dengan Amrozi (pelaku Bom Bali I) dan saudara-saudaranya itu ..., ibu saya masih sepupu tingkat dua, bapaknya mereka masih sepupu dengan kakek saya.

Karena masih ada kekerabatan itulah maka ketika ia sudah keluar dari pondok pesantren dan melanjutkan di Sekolah Teknik Menengah (STM), ia masih menjalin komunikasi dengan para guru agama di sana. Kemudian peristiwa Bom Bali I terjadi. Peristiwa itu menjadi awal mula keterlibatannya dalam jaringan. Ia bercerita:

Saat itu, usia saya baru 20 tahun. Saya tahu para ustaz itu simpatisan pelaku bom Bali, ketika mereka malah memuji aksi para pelaku tiap kali ada pemberitaan di media massa ... para ustaz itu pada awalnya hanya memuji, lama-lama mereka mulai menerangkan dalil dan alasan para pelaku itu melakukan aksi pengeboman Bali.

Pengaruh para guru agama yang masih terhitung memiliki ikatan kerabat itu membuat
Raudan perlahan mulai meyakini dalil agama yang membenarkan aksi Bom Bali bahkan mulai mengagumi heroisme para pelakunya. Ia bercerita dalam bukunya:

Saya malah mulai menganggap apa yang mereka lakukan itu adalah sesuatu yang hebat. Heroik! Persis ketika saya memuji para pelaku serangan 11 September 2001 di Amerika Serikat alias tragdi WTC.

Pada akhirnya, Raudan menyadari bahwa sebagian guru agamanya adalah kader JI, dan dia bersama beberapa temannya adalah binaan dari jaringan JI. Setelah mengetahui fakta ini, Raudan sempat terkejut namun tidak surut. Justru ia mulai mengalami perasaan bersemangat dan bangga menjadi bagian dari kelompok yang diburu pemerintah.

Jika banyak anak muda yang suka balapan, panjat tebing, ataupun berbagai olahraga ekstrim lain unjuk diri, saya sendiri merasa cukup menjadi anggota kelompok berbahaya menurut negara.

Selama menjadi bagian dari jaringan, Raudan bertemu dengan banyak orang dengan cerita yang sama. Kisah peristiwa ajaib di medan jihad (konflik Ambon) yang mengukuhkan kebenaran aksi 'jihad', kemuliaan para mujahid dan pelaku Bom Bali, dan heroisme perjuangan membela Agama dari penindasan tiran Amerika dan sekutunya. Raudan bercerita dalam bukunya konteks pertemuan itu adalah ketika ratusan tamu datang ke pondok pesantren saat menjelang 
dan sesudah eksekusi mati trio pelaku Bom Bali I (Mukhlas, Amrozi, Imam Samudra).

Semangat untuk menghidupkan jihad di Indonesia itu semakin membuncah ketika saya bertemu dengan ratusan atau bahkan ribuan orang yang hadir ... saya makin yakin! Sebab, kehadiran ribuan orang itu, saya merasa ternyata banyak orang yang bersimpati pada apa yang dilakukan para almarhum trio Bom Bali I itu.

Ia mulai aktif menjalin komunikasi dengan rekan-rekan sepemahaman melalui mailing lists forum-forum jihadi, dan chatting melalui mIRC. Menggunakan komputer dan berselancar di internet memang menjadi minatnya sejak sekolah dan lulus dari STM. Dari komunikasi melalui internet itulah berkembang solidaritas jihad global yang semakin menguatkan kebanggaannya bahwa apa yang ia dan jaringannya yakini dan lakukan itu tidak hanya berskala nasional tetapi juga bersifat global. Ia menambahkan, menyaksikan video-video dan gambar dari medan jihad dengan nasyid (lagu religius) penyemangat dalam Bahasa Arab melalui internet, telah membakar semangatnya. Ia menulis dalam bukunya:

Saya berpikir, berarti pendukung ini tidak hanya di Indonesia. Kaena ini umat Muslim, sesama Muslim yang sedang memperuangkan agamanya. Tidak peduli dari negara mana, belahan dunia yang mana yang penting satu tujuan. Semangat saya semakin terbakar!
Ada perasaan berbeda dalam diri saya ketika hanya membaca dan mendengar kisah seputar jihad ... dari para ustaz dibandingkan dengan sudah menyakikan langsung melalui video atau gambar... menyaksikan langsung ... kekejian yang dialami kaum Muslimin. Bagaimana heoriknya para mujahidin dalam perang melawan musuh-musuhnya. Meskipun kalah persenjataan, kalah jumlah dan kalah kualitas (dari) musuh yang dihadapi.

Nasyid itu selalu menjadi back song ... video propaganda jihad... Ada kebanggaan tersendiri bagi ikhwan yang mendendangkan nasyid berbahasa Arab itu.

Semangat muda dan pertemuannya dengan role models, yaitu guru agama dan orangorang yang telah menjalankan 'jihad' secara langsung dalam konflik Ambon, semakin memantapkan langkah Raudan dalam menjalankan perannya di jaringan teroris. Ia rutin mengunjungi beberapa guru agamanya dan teman-temannya dulu sesama di pesantren yang dihukum penjara karena terlibat dalam kasus Bom Bali I. Ikatannya dengan JI menjadi semakin kuat saat ia menikah pada usia 23 tahun atas bantuan para ustaz dalam jaringan JI. Setahun kemudian ia memiliki seorang anak.

Ia mulai bertemu secara langsung dengan kawan-kawannya yang semula dikenal melalui dunia maya dan mulai berbagi peran dalam menjalankan perjuangan yang saat itu ia yakini. Partisipan mengaku perannya dalam 
jaringan adalah sebagai penghubung dan penggalang dana. Ia mendapatkan instruksi dari atasan di JI, namun ia berhubungan juga dengan jaringan Mujahidin Indonesia Barat (MIB) dan Mujahidin Indonesia Timur (MIT). Ia berperan dalam menyiapkan kader yang dilibatkan dalam pelatihan dan aksi yang dilakukan jaringan, dan memasok dana atau senjata yang dibutuhkan jaringan.

Namun, ada yang menarik dari kisah partisipan. Meskipun memiliki semangat kuat dalam menjalankan peran di jaringan teroris, nyatanya Raudan tetap tidak bisa meninggalkan keluarganya. Istri, anak, dan orang tuanya tetap menjadi pertimbangan dalam menerima peran dan tanggungjawab dalam jaringan. Ia beruntung karena istrinya bukan bagian dari JI dan tidak tahu tentang operasi JI meski berdasarkan pengakuannya keluarganya mungkin telah menduganya. Fakta ini berbeda dengan kecenderungan kelompok teroris pro-ISIS (Islamic State of Iraq and Syiria) di Indonesia saat ini yang melibatkan perempuan dalam aksi terorisme baik sebagai motivator maupun eksekutor.

Karena keterikatannya dengan keluarganya, Raudan menolak ajakan aksi, dan kemudian berpisah dengan, kawan-kawannya yang akhirnya melakukan operasi perampokan Bank CIMB di Medan tahun 2010.

Tetapi saya menetapkan sebuah prinsip utama dalam keterlibatan saya, bahwa apapun tugas yang akan diberikan kepada saya, saya tidak mau meninggalkan kewajiban saya sebagai seorang suami, seorang ayah, dan seorang anak pertama.

Karena saya anak pertama pak... pasti jadi anak yang menjadi tumpuan orang tua. Karena saya gede duluan, maka pasti birrul walidain itu menjadi nomor satu di tangan saya, bukan adik-adik saya.

Birrul walidain adalah Bahasa Arab yang berarti berbakti kepada kedua orang tua. Keluarga telah menyelamatkan Raudan dari keterlibatan yang lebih dalam di jaringan terorisme. Raudan hanya menerima peran dan tanggungjawab yang tidak berisiko mengorbankan diri atau harus meninggalkan tugasnya untuk keluarga dan orang tuanya. Saya itu naluri, jiwa apa, challenging-nya saat itu kuat, tapi di satu sisi saya juga nggak ingin orang tua, keluarga saya susah gara-gara saya ingin mencoba hal baru (dalam jaringan).

\section{Terbukanya pikiran}

Saat itu Juni 2014, Raudan memiliki janji dengan kawannya di daerah Pasar Minggu, Jakarta selatan untuk mengatur keberangkatan seseorang yang akan berangkat ke Suriah bergabung dengan ISIS. Ia menunggu di dekat sebuah masjid sambil makan bakso di sebuah warung. Saat itulah ia ditangkap. Ia sudah merasa diawasi namun tidak menduga. Beberapa orang duduk di samping kanan dan kirinya. Tiba-tiba saja ada suara 'jangan bergerak' bersamaan dengan todongan senjata. 
Ketika interogasi, ia beruntung tidak mendapatkan siksaan fisik. Ia hanya di bawa beberapa hari berkeliling entah kemana dalam kondisi mata tertutup dan tidak bisa melakukan apapun kecuali ke kamar mandi. Dalam waktu itu ia kerap mendapatkan ancaman psikologis.

Saya mendapat acaman psikologis. Kalau saya tidak mengaku, dua orang yang saya bawa akan ditangkap... mereka tidak bersalah. Mereka mau ke Suriah. Saat itu belum ada deklarasi ISIS. ... Mereka akhirnya tidak ditahan

Setelah mengakui keterlibatannya, ia kemudian ditahan di Rutan Mako Brimob sambil menunggu dan menjalani persidangan. Vonis 4 tahun 10 bulan akhirnya didapatkan. Ia bersyukur hukumannya jauh lebih rendah dari 7 tahun yang dituntutkan oleh jaksa.

Dalam penjara, Raudan mulai merenungkan hidupnya. Saat itu ia berusia 32 tahun. Ia menjadi jauh dari keluarga dan merasa sedih karena kasusnya dapat berdampak pada keluarganya. Dalam Rutan itu ia dikunjungi beberapa ahli agama dan akademisi dari perguruan tinggi. Ini merupakan bagian dari program deradikalisasi yang dijalankan di penjara. Raudan bercerita dialognya dengan salah seorang ahli itu yang membuatnya mulai mengevaluasi keterlibatannya dalam jaringan terorisme. Seperti yang ia ceritakan:

Titik balik saya ketika bertemu seorang rekan, saya diskusi di Mako Brimob. Saya diajak bicara, ketika membicarakan tentang untuk siapa memperjuangkan ini? Ya saya jawab Islam! (Dia tanya) Islam yang mana?

Ahli yang menemuinya itu kemudian menyentuh keluarganya yang harus menanggung beban dari kasus yang dialaminya. Raudan mengaku dialog tentang keluarga itu seperti membangunkannya. Sejak lama ia sudah bertekad untuk bertanggungjawab pada keluarganya, namun arti pentingnya baru terasa ketika ia ditangkap dan dipenjara. Ia mengungkapkan peran orang tuanya yang membuatnya berkomitmen untuk lepas dari jaringan teroris seperti disampaikannya di media online Republika (2018, 25 September):

Karena yang paling gak putus asa untuk menyadarkan ya keluarga, ada, luluh pasti. Orang tua gak akan putus asa menasihati anaknya, banyak yang berubah setelah itu.

Saya sudah mantap. Selama ini salah, saya ingin menjalani hukuman ini ikhlas sebagai pertanggungjawaban perbuatan saya.

Setelah mendapat vonis, Raudan dipindah ke Rutan Mako Brimob Cabang salemba. Saat itulah ia berkesempatan untuk mulai menjauh dari sesama narapidana terorisme. Rekanrekannya menyadari hal itu. Ia dianggap tidak bisa menjaga hubungan dengan mereka. Ia mulai diperlakukan sebagai orang luar. Raudan justru melihatnya sebagai peluang. Ia mulai merefleksikan kembali perjalanannya 
hingga terlibat dalam kasus terorisme dan kemudian mulai menuliskannya. Proses menulis kisah hidupnya ini tampak sekaligus menjadi sarana bagi Raudan untuk mengevaluasi keyakinan ekstrem yang sebelumnya ia yakini. Ia juga mulai memperbanyak pergaulannya dengan narapidana kriminal umum. Karena hal itu ia sempat mendapatkan julukan "teroris gaul". Pengalaman ini memberinya sentuhan rasa kemanusiaan karena berkesempatan bergaul orang dari beragam latar belakang dengan berbagai masalah kriminal.

Ketika dalam penjara itu saya lebih banyak belajar, mempelajari proses awal saya menjadi radikal itu bagaimana... Ketika dalam penjara itulah saya belajar nilai-nilai kemanusiaan, saya belajar membaur dengan siapa pun itu. Saya membuka diri.

Menyangkut istri dan anaknya, partisipan mengaku tidak terlalu merasa tertekan dengan kebutuhan hidup mereka mengingat istri dan anaknya ditopang oleh orang tuanya. Namun, Istrinya kemudian mulai dapat merintis usaha ekonomis kecil-kecilan saat ia masih di penjara. Raudan juga beruntung karena ia dapat menghubungi keluarganya secara rutin dari penjara melalui telepon berbayar. Ia mengaku berhasil mendapatkan uang di penjara dari narapidana lain yang mendapatkan jasa dan barang jualan tertentu yang diijinkan di dalam penjara. Ia bahkan dapat mengirimkan sejumlah uang untuk keluarganya beberapa kali. Menjelang bebas, Raudan sudah mulai selesai menulis draft buku refleksi kehidupannya. Ia mengaku juga tertarik untuk menulis novel berdasarkan kisah hidupnya.

\section{Menjadi aktivis perdamaian}

Setelah bebas dari penjara dengan pembebasan bersyarat pada Oktober 2017, Raudan pulang ke rumah di mana anak, istri, dan orang tuanya tinggal dan yang menjadi rumahnya sejak ia kecil. Arah perubahan diri Raudan menuju moderasi menjadi lebih mudah mengingat para tetangga dan masyarakat sekitar rumahnya di desa tidak banyak tahu tentang kasusnya. Keluarganya hanya bercerita ke tetangga bahwa ia merantau. Meskipun pada akhirnya mereka tahu kasusnya setelah ia bebas, berkat keluarganya yang berhubungan baik dengan warga desa, dan cara komunikasi Raudan, ia tidak mendapat reaksi yang membebani.

Saya biasa merantau sejak tahun 2007, jadi kalau saya tidak pulang-pulang itu orang tidak heran, tidak ada yang tanya. Paling ketika lebaran mereka baru ingat saya. Jadi nyaris tidak ada yang tahu masalah saya.

Saya bersyukur ditangkap di Jakarta, tidak di rumah... Kalau saya ditangkap di rumah pasti akan ribut satu kampung, pasti heboh. Dan saya yakin keluarga saya pasti sulit untuk meng-counter isu radikal itu pada masyarakat.

Peneliti : Lalu, tetangga di rumah 
akhirnya tahunya bagaimana?

Partisipan : Setelah saya pulang.

Peneliti : Oh setelah bebas ya?

Partisipan : Saya gampang (ceritanya) : Saya

kerja di Jakarta, bantu teman, ternyata dia terlibat terorisme, ditangkap. Saya ikut ditangkap.

Hidup di desa dengan orang tuanya yang biasa berhubungan baik dengan warga lain memberi partisipan modal kepercayaan dari tetangga hingga ceritanya dapat diterima. Upayanya untuk berbaur setelah bebas, terutama dengan mendatangi undangan acara warga desa dan ikut tahlilan (zikir dan doa bersama) di rumah tetangga menjadi cara manjur Raudan selanjutnya agar diterima masyarakat.

Ketika bebas, Raudan mendapatkan sedikit modal dari kepolisian dan berpikir untuk usaha membuat dan berjualan roti. Saat itu usianya menjelang 36 tahun. Rencana usaha roti tidak berjalan. Kapolres Tuban saat itu datang mengunjunginya dan bertanya mau usaha apa? Ia menjawab mau membantu usaha bapaknya jual-beli burung. Ia menuliskan ini dalam artikel yang diterbitkan di website LSM-nya:

Pada saat itu saya meyakini, bahwa dengan membantu orangtua akan terbuka peluang rezeki yang lebih besar. Saya hanya ingin fokus meyakinkan orang tua bahwa saya benar-benar ingin jadi anak yang berbakti.

Kondisi ekonomi keluarganya yang cukup mandiri karena usaha kecil-kecilan sang istri, ditambah dukungan dari orang tuanya, membuat Raudan memikirkan tentang aktivitas menulisnya kembali. Ketika di penjara, ia sempat memberikan draft buku refleksi hidupnya itu pada akademisi dari perguruan tinggi (PT) dengan maksud untuk dibantu penerbitannya. Ternyata ia kemudian dikontak akademisi tersebut, dan diundang untuk berdiskusi dengan mahasiswa pascasarjana di PT itu di Jakarta untuk memperbaiki draft bukunya. Ia merasa diapresiasi ketika pada saat yang sama, royalti buku tersebut dibeli dan dia diminta merevisinya. Ia kemudian membeli PC bekas dari uang royalti tersebut dan mulai merevisi sesuai permintaan.

Tak lama kemudian ia mendapatkan nomor kontak seorang aktivis LSM berbasis di Jakarta yang menjadi perintis upaya pemberdayaan mantan narapidana terorisme. Meskipun ia bukan peserta yang diundang, ia tetap datang dengan biaya sendiri untuk menunjukkan draft novelnya. Melampaui ekspektasinya, ia tidak hanya mendapatkan masukan tapi juga penawaran yang mengubah hidupnya. Ia menulis dalam artikelnya di website LSM-nya:

Tapi yang terjadi malah di luar ekspektasi. Saya mendapatkan lebih dari yang diharapkan... saya ditawari untuk menjadi kontributor ... dan menulis buku tentang pengaruh internet pada pola radikalisasi di Indonesia berdasarkan pengalaman saya. 
Raudan menjadi lebih bersemangat. Melalui LSM itu, Raudan mulai menemukan arah baru dalam hidupnya yang prospektif untuk mengembangkan minat menulisnya. Ia juga belajar komunikasi publik dan menjadi narasumber dalam berbagai kampanye kontraekstremisme kekerasan. Raudan membuktikan titik balik hidupnya yang lebih bermakna dengan berkontribusi bagi masyarakat sesuai kemampuan yang ia bisa. Raudan memaknai kerjanya dalam kampanye kontraekstremisme inj sebagai penebusan atas kesalahan yang pernah ia lakukan. Ia merasa bermakna dengan menyeru anak-anak muda agar tidak termakan propaganda yang dulu menjebaknya.

Saya tidak boleh mengulangi kesalahan saya. Cara saya supaya tidak mengulangi kesalahan saya adalah mengajak orang agar tidak melakukan kesalahan yang pernah saya lakukan.

\section{Diskusi}

Penelitian ini menemukan bahwa keterlibatan subjek dalam jaringan terorisme terutama ditentukan oleh kedekatannya dengan orangorang yang telah bergabung dalam jaringan teroris. Raudan tumbuh sebagai remaja di lingkaran para guru agama yang menjadi simpatisan, bahkan bagian dari, kelompok ekstrem pelaku terorisme. Mereka masih terhitung kerabat dari pihak ibunya. Periode perkembangan psikologisnya sebagai anak muda yang sedang dalam upaya mencari peran dan identitas (Erikson, 1968, dalam Côté, 2018) tampak berperan dalam proses bergabungnya Raudan dalam jaringan teroris. Ia merefleksikan perasaan bangga karena menjalani pengalaman menantang sebagai bagian dari kelompok yang menjadi musuh negara. Pengalaman personal partisipan ini tidaklah unik mengingat sejumlah penelitian telah menemukan bahwa salah satu motivasi utama anak muda bergabung dalam terorisme adalah untuk mencari status, identitas, pengakuan diri, dan sensasi dari sebuah petualangan (Gómez dkk., 2021; Kruglanski dkk., 2014; Venhaus, 2010). Pengaruh lingkaran kerabat atau keluarga dalam perekrutan jaringan terorisme yang ditunjukkan penelitian ini juga meneguhkan temuan sebelumnya bahwa salah satu faktor utama bergabungnya seseorang dalam jaringan terorime adalah ikatan keluarga terutama melalui saudara atau kerabat (Hafez, 2016; Sulastri, 2010; Ismail, 2006).

Namun, temuan menarik dari kisah partisipan adalah bahwa ikatan kerabat keluarga tidak hanya menjadi faktor penyebab keterlibatan dalam jaringan teroris, namun juga sekaligus menjadi faktor penghambat yang membuat partisipan penelitian in tidak terjebak lebih dalam di jaringan teroris. Rasa tanggungjawab pada, dan ikatan emosinya dengan, orang tua serta anak dan istrinya menyelamatkannya dari pilihan peran yang berisiko. Bahkan 
faktor keluarga ini pula yang paling berperan bagi partisipan penelitian ini untuk berhenti dari jaringan terorisme dan mulai menolak ideologinya. Temuan ini sesuai dengan hasil penelitian sebelumnya secara global yang menyimpulkan pentingnya peran keluarga dalam mencegah orang terlibat dengan, dan membuat orang berhenti dari, kelompok estrem kekerasan (El-Amraoui \& Ducol, 2019; Kohler, 2016; Weggemans \& De Graaf, 2015). Sebaliknya, temuan ini menjadi berbeda dan bertolak belakang dengan hasil penelitian Sikkens dkk. (2017) terhadap 11 mantan radikal ekstrem lintas ideologi termasuk ekstremis Islam dan Sayap Kanan yang menyatakan tidak ada pengaruh langsung dari orangtua terhadap proses deradikalisasi.

Proses perubahan diri Raudan menuju moderasi juga tidak lepas dari tersedianya jaringan sosial alternatif di luar kelompok lamanya selama dan setelah ia bebas dari penjara. Pertemuannya dengan seorang ahli agama yang mengunjunginya di penjara dengan pertanyaan mendasar "berjuang untuk siapa?" "Islam yang mana?" membuat Raudan mulai ragu dengan keyakinan ekstremnya. Apalagi setelah dampak kasus terorismenya pada keluarganya diungkit sang ahli.pertemuan itu melahirkan keinginan kuat Raudan untuk mulai menulis kisah hidupnya sebagai refleksi. Wawasan ini juga sekaligus mengindikasikan perlakuan petugas penjara pada Raudan yang konstruktif. Raudan berpeluang untuk melakukan aktivitas menulis dalam penjara karena situasi penjara yang kondusif baginya. Sekalipun hanya implisit dalam cerita Raudan, tampak bahwa pendekatan pihak petugas terhadapnya cenderung manusiawi. Hal ini akhirnya memperkuat motivasinya untuk memilih hidup baru di luar jaringan lama. Pendekatan humanis dan mengedepankan relasi interpersonal yang positif terhadap narapidana terorisme memang terbukti efektif dalam mencegah mantan narapidana terorisme kembali ke jaringan lamanya setelah ia bebas (Putra dkk., 2018). Pergaulan Raudan dengan narapidana umum dari beragam latar belakang dan masalah hukum juga turut berperan dalam menimbulkan rasa empati atas dasar hubungan sebagai manusia (Alfithon \& Syafiq, 2021). Inisiatif partisipan dalam menjalani hubungan sosial melampaui lingkaran sesama narapidana terorisme ini merupakan tanda bahwa telah terjadi perubahan pikiran dan keyakinan yang cukup mendasar, yaitu penghargaan atas perbedaan dan keragaman. Sikap ini merupakan salah satu ciri perubahan partisipan ke arah yang lebih moderat (Sukabdi, 2015).

Faktor penerimaan masyarakat desa di mana ia tumbuh sejak kecil terhadap keluarganya membuat Raudan memiliki landasan yang kuat dalam menjalan peran baru yang lebih positif. Penelitian menemukan bahwa penerimaan masyarakat terhadap mantan 
narapidana teroris terbukti berperan kuat dalam proses reintegrasi mereka dalam kehidupan bermasyarakat (Abuza, 2009), Faktor hubungan sosial alternatif yang tersedia bagi Raudan dari kalangan akademisi dan terutama LSM setelah ia bebas dari penjara juga dapat menjelaskan mengapa ia hingga sekarang dapat bertahan dalam peran dan identitas baru di luar jaringan kelompok teroris. Penelitian memang menunjukkan betapa pentingnya hubungan sosial baru dalam membuat mantan penganut ideologi ekstrem kekerasan berhenti secara berkelanjutan dari kelompok lamanya (Harris dkk., 2017; Koehler, 2016; Barrelle, 2015).

Dalam konteks Indonesia, apa yang dialami Raudan menjadi kasus yang berbeda dengan temuan Hwang (2018) yang mengungkapkan bahwa sebagian mantan narapidana terorisme yang ditelitinya di Indonesia memang telah berhenti dari jaringan teroris, namun berakhir pada kelompok-kelompok simpatisan yang dekat dengan jaringan lamanya. Hwang (2018) menyimpulkan bahwa proses perubahan para mantan narapidana terorisme yang demikian ini lebih tepat disebut sebagai disengagement dari pada deradikalisasi karena mereka pada dasarnya masih meyakini ideologi ekstrem. Partisipan Raudan berhasil melepaskan diri dari jaringan lamanya, menolak ideologi terorisme, dan bergabung dengan jaringan sosial baru yang mengkampanyekan kontra- terorisme. Menurut Chalmers (2017), karakteristik ini menunjukkan bahwa Raudan telah mengalami tahap deradikalisasi paripurna (fully deradicalised) yang membedakannya dengan mantan anggota jaringan teroris lainnya yang mungkin sudah berhenti namun masih percaya aksi bersenjata tetap dilakukan jika situasi menuntutnya (provisionally deradicalized).

Selain motivasi diri yang kuat dari partisipan Raudan untuk menemukan cara menjalani hidup baru melalui menulis dan mengkampanyekan kontra-ekstremisme, ia mendapatkan landasan yang luat saat ini karena ditopang oleh LSM yang memfasilitasi minatnya, serta pertemuannya dengan berbagai segmen masyarakat yang membuatnya memiliki hubungan yang luas dan beragam. Hal ini membantu Raudan dalam mempertahankan pendiriannya untuk menolak ideologi dan aksi ekstrem atas nama agama yang sebelumnya ia percaya. Komunitas sosial dan hubungan baru yang ia jalani saat ini telah memberinya kekuatan untuk membentenginya dari respon negatif dan merendahkan yang diberikan oleh mantan rekannya yang masih ekstrem atau aktif dalam jaringan. Seperti ditemukan oleh Syafiq (2019), respon negatif yang merendahkan itu terutama dalam bentuk tuduhan seperti pengecut, meninggalkan kemuliaan perjuangan demi dunia, tidak teguh pendirian 
dan tuduhan sejenisnya yang jika tak mampu diatasi akan dapat menurunkan rasa diri yang positif (positive sense of self).

Dalam beberapa pertemuan dengan peneliti, partisipan membanggakan dirinya yang telah menghasilkan beberapa buku dan puluhan artikel baik yang dimuat dalam website LSMnya saat ini maupun di media nasional. Raudan telah menemukan arti penting diri (selfsignificance) dari menulis dan menjadi penyeru pesan kontra ideologi ekstrem kekerasan. Seperti yang dikemukakan oleh Kruglanski et al (2014), pencarian signifikansi pribadi memainkan peran penting baik dalam bergabungnya seseorang ke, maupun keluarnya dia dari, jaringan berideologi ekstremisme kekerasan. Deradikalisasi dapat terjadi ketika para ekstremis kekerasan mulai menganggap cara kekerasan sebagai tidak lagi efektif dalam memberikan arti diri.

Pencarian signifikansi pribadi ditentukan oleh banyak faktor mulai dari motivasi diri, narasi ideologis yang membenarkan atau menolak ekstremisme kekerasan, dan jaringan sosial yang memengaruhi narasi ideologis tersebut (Webber \& Kruglansky, 2018). Hwang (2017) juga menemukan bahwa proses deradikalisasi dan disengagement di kalangan jihadis Indonesia didorong oleh banyak faktor termasuk faktor psikologis, hubungan sosial, dan kepentingan strategis seperti fasilitas pekerjaan atau sumber nafkah. Faktor-faktor tersebut seringkali saling berhubungan satu sama lain dalam kombinasi tertentu. Pada partisipan Raudan, ketiga faktor tersebut sama terlibat karena aktivitas menulis dan penyeru ideologi moderat yang damai bersama lembaganya saat ini telah memenuhi minat pribadi, jaringan hubungan sosial yang baru, dan sumber ekonomi untuk kehidupannya dan keluarganya. Kepastian sumber penghidupan untuk diri dan keluarga dan keterampilan yang membuat para mantan teroris dapat mandiri dalam kehidupan normal di masyarakatnya serta arti diri dalam pilihan hidunya saat ini telah terbukti sebagai faktor penting yang membuat mereka tidak kembali ke jaringan lama setelah dibebaskan dari penjara (Rabasa dkk., 2010; Mullins, 2010).

\section{SIMPULAN}

Penelitian ini menyimpulkan bahwa proses perubahan diri partisipan panilitian ini didorong oleh motivasi yang kuat untuk mengubah hidup dan pertimbangan demi kebaikan keluarga, dalam hal ini adalah orang tua partisipan. Kemudahan partisipan ini keluar dari jaringan lamanya juga ditentukan oleh minatnya yang berbeda. Ia tidak menyukai aktivitas fisik hingga menolak terlibat dalam konflik fisik di Ambon dan memilih peran dalam jaringan yang tidak secara langsung membuatnya terlibat sebagai pelaku langsung atau eksekutor aksi terorisme. Partisipan Raudan lebih menikmati aktivitas melibatkan ekspresi pikiran yang pada 
akhirnya menemukan muaranya melalui menulis. Dapat dikatakan bahwa minat menulisnya ini telah mengantarkannya pada perjalanan menuju moderasi. Ia bertemu dengan orang-orang yang membantunya menemukan jaringan sosial alternatif yang membuatnya dapat mengaktualisasikan minat menulisnya. Ia kemudian menikmati peran barunya sebagai pembawa pesan damai kontra narasi ekstremisme. Partisipan Raudan tidak sekedar memiliki kebanggan sebagai orang kredibel (credible voice) yang dapat mengkampanyekan kontra-ekstremisme. Ia juga menemukan sumber penghidupan diri dan keluarganya dari aktivitas yang diminatinya bersama LSM yang telah sukses memfasilitasinya untuk mencapai perannya saat ini. Pertemuan yang mutual antara partisipan Raudan dan LSM tempatnya saat ini beraktivitas telah menentukan arah hidup yang lebih optimis pada diri prtisipan sebagai mantan teroris. Bahkan lembaga sosial tempatnya saat ini berkarya telah memberinya landasan untuk siap berkontra dan melawan kelompok dan ideologi ekstremisme yang dulu diyakininya. 
DAFTAR RUJUKAN

Abuza, Z. (2009). The Rehabilitation of Jemaah Islamiyah Detainees in South East Asia: A Preliminary Assessment. In T. Bjorgo and J. Horgan (Eds.). Leaving Terrorism Behind: Individual and Collective Disengagement (pp. 193211). Routledge.

Alfithon, A. M., \& Syafiq, M. (2021). Selfcompassion of terrorist prisoners undergoing deradicalization program. Jurnal Psikologi Ulayat: Indonesian Journal of Indigenous Psychology. (online first). https://doi.org/10.24854/jpu343

Andrie, T. (2011). Kehidupan di Balik Jeruji: Terorisme dan Kehidupan Penjara di Indonesia. Position Paper No. 02. Institute for International Peace Building Jakarta.

https://pdfcoffee.com/qdownload/kehid upan-di-balik-jeruji-pdf-free.html

Badan Pembinaan Hukum Nasional (BPHN). (2020, 17 Juli). Turun ke Lapas, BPHN tangkal penyebaran paham radikalisme dikalangan napi. https://lsc.bphn.go.id/news?nid=1141\&i d_page $=108$

Barrelle, K. (2015). Pro-integration: disengagement from and life after terrorism. Behavioural Sciences of Terrorism and Political Aggression,7(2), 129-142. https://doi.org/10.1080/19434472.2014. $\underline{988165}$

Bjorgo, T. (2009). Processes of disengagement from violent groups of the extreme right. In T. Bjorgo and J. Horgan (Eds.).
Leaving Terrorism Behind: Individual and Collective Disengagement (pp.3048). Routledge.

Clubb, G. (2014). "From Terrorists to Peacekeepers": The IRA's disengagement and the role of community networks. Studies in Conflict and Terrorism. 37(10), 842-861. https://doi.org/10.1080/1057610X.2014 .941434

Chalmers, I. (2017). Countering Violent Extremism in Indonesia: Bringing Back the Jihadists. Asian Studies Review, 41(3), 331-351. https://doi.org/10.1080/10357823.2017. $\underline{1323848}$

Cherney, A. (2018). Evaluating interventions to disengage extremist offenders: A study of the proactive integrated support model (PRISM). Behavioral Sciences of Terrorism and Political Aggression, 12(1),17-36. https://doi.org/10.1080/19434472.2018. $\underline{1495661}$

Côté, J. E. (2018): The Enduring Usefulness of Erikson's Concept of theIdentity Crisis in the 21st Century: An Analysis of Student Mental Health Concerns. Identity: An International Journal of Theory and Research, 18(4), 251-263. http://dx.doi.org/10.1080/15283488.201 $\underline{8.1524328}$

El-Amraoui, A. F., \& Ducol, B. (2019). Family-Oriented P/CVE Programs: Overview, Challenges and Future Directions. Journal for Deradicalization, 20, 191-230. https://journals.sfu.ca/jd/index.php/jd/ar ticle/view/255/177 
Garfinkel, R. (2007). Personal transformations: Moving from violence to peace. United States Institute of Peace.

https://www.usip.org/publications/2007 /04/personal-transformations-movingviolence-peace

Gómez, Á., Martínez M., Martel, F. A., LópezRodríguez, L., Vázquez, A., Chinchilla, J., Paredes, B., Hettiarachchi, M., Hamid, N., \& Swann, W. B. (2021). Why People Enter and Embrace Violent Groups. Frontiers in Psychology,11, 3823.

https://doi.org/10.3389/fpsyg.2020.614 $\underline{657}$

Hafez, M. M. (2016). The Ties that Bind: How Terrorists Exploit Family Bonds. CTC Sentinel, 9(2), 15-17. https://ctc.usma.edu/the-ties-that-bindhow-terrorists-exploit-family-bonds/

Hagemaster J. N. (1992). Life history: A qualitative method of research. Journal of Advanced Nursing, 17(9), 1122-1128. https://doi.org/10.1111/j.13652648.1992.tb02047.x

Hettiarachchi, M. (2018). Rehabilitation to deradicalise detainees and inmates: A counter-terrorism strategy. Journal of Policing, Intelligence and Counter Terrorism, 13(2), 267-283. https://doi.org/10.1080/18335330.2018. $\underline{1476774}$

Horgan, J., \& Altier, M. B. (2012). The future of terrorist de-radicalization program. GeorgetownJournal of International Affairs, 13(2),83-90. https://www.jstor.org/stable/43134238
Horgan, J., \& Braddock, K. (2010). Rehabilitating the terrorists?: Challenges in assessing the effectiveness of de-radicalization programs. Terrorism and Political Violence,22(2),267-291. http://dx.doi.org/10.1080/09546551003 $\underline{594748}$

Hwang, J. C. (2018). Why terrorist quit: The disengagement of Indonesian jihadist. Cornell University Press.

Hwang, J. C. (2017). The Disengagement of Indonesian Jihadists: Understanding the Pathways. Terrorism and Political Violence. 29(2), 277-295. https://doi.org/10.1080/09546553.2015. $\underline{1034855}$

Harris, K. J., Gringart, E. \& Drake, D. (2017). Leaving ideological groups behind: A model of disengagement. Behavioural Sciences of Terrorism and Political Aggression, 10(2), 91-109. https://doi.org/10.1080/19434472.2017. $\underline{1299782}$

Ismail, N. H. (2006). The Role of Kinship in Indonesia's Jemaah Islamiya. Terrorism Monitor, Volume: 4 Issue: 11. https://jamestown.org/program/the-roleof-kinship-in-indonesias-jemaahislamiya/

Koehler, D. (2017). How and why we should take deradicalization seriously. Nature Human Behaviour, 1, 0095. http://dx.doi.org/10.1038/s41562-0170095

Kompas.com (2018, Mei 30). BNPT: Ada 289 Narapidana Terorisme yang Tersebar di 113 
https://nasional.kompas.com/read/2018/ 05/30/12294981/bnpt-ada-289narapidana-terorisme-yang-tersebar-di113-lapas.

Kruglanski, A. W., Gelfand, M. J., Belanger, J. J., Sheveland A., Hetiarachchi, M., \& Gunaratna, R. (2014). The Psychology of Radicalization and Deradicalization: How Significance Quest Impacts Violent Extremism. Political Psychology, 35(1), 69-93. https://doi.org/10.1111/pops.12163

Moskalenko, S. \& McCauley, C. (2009). Measuring Political Mobilization: The Distinction Between Activism and Radicalism. Terrorism and Political Violence, $21(2): 239$ - 260. https://doi.org/10.1080/0954655090276 $\underline{5508}$

Mullins, S. (2010). Rehabilitation of Islamist terrorists: Lessons from Criminology. Dynamics of Asymmetrics Conflict, 3(3), 162-193.

doi: https://doi.org/10.1080/17467586.2010. $\underline{528438}$

Noricks, D. M. E. (2009). Disengagement and Deradicalization: Processes and Programs," in Davis, Paul K. and Cragin, Kim. (eds.). Social Science for Counterterrorism: Putting the Pieces Together. RAND Corporation. http://www.rand.org/pubs/monographs/ 2009/RAND_MG849.pdf

Putra, I. E., Danamasi, D. O., Rufaedah, A., Arimbi, R. S., \& Priyanto, S. (2018). Tackling Islamic terrorism and radicalism in Indonesia by increasing the sense of humanity and friendship. In B. L. Cook (Ed.). Handbook of research on examining global peacemaking in the digital age (pp. 94-114). IGI Global.

Rabasa, A., Pettyjohn, S. L., Ghez, J. J., \& Boucek, C. (2010). Deradicalizing Islamist Extremists. RAND Corporation. http://www.rand.org/pubs/monographs/ 2010/RAND_MG1053.pdf

Riessman, C. K. (1993). Narrative analysis. Sage Publications

Schmid, A. P. (2013). Radicalisation, deradicalisation, counter-radicalisation: A conceptual discussion and literature review. The International Center for Counter-Terrorism - The Hague, 4(2), 1-105. http://dx.doi.org/10.19165/2013.1.02

Sikkens, E., Van San, M., Sieckelinck, S., \& De Winter, M. (2017). Parental Influence on Radicalization and DeRadicalization according to the Lived Experiences of Former Extremists and their Families. Journal for Deradicalization, $\quad 12, \quad 192-225$. https://journals.sfu.ca/jd/index.php/jd/ar ticle/view/115

Sukabdi, Z. A. (2015). Terrorism in Indonesia: A review on rehabilitation and deradicalization. Journal of Terrorism Research, 6(2),36-56. https://doi.org/10.15664/jtr.1154

Sulastri, O. (2010). Jemaah Islamiyah: Of Kin and Kind. Journal of Current Southeast Asian Affairs, 29(2), 157-175. https://doi.org/10.1177\%2F1868103410 $\underline{02900205}$ 
Sumpter, C. (2017). Countering violent extremism in Indonesia: priorities, practice and the role of civil society. Journal for Deradicalization, 11, 112146.

http://journals.sfu.ca/jd/index.php/jd/art icle/viewFile/103/86

Syafiq, M. (2019). Deradicalization and disengagement from terrorism and threat to identity: An analysis of former jihadist prisoners' accounts. Psychology and Developing Societies, 31(2), 227251.

https://doi.org/10.1177/0971333619863 $\underline{169}$

Venhaus, J. M. (2010). Why Youth Join alQaeda. Special Report, 236. United States Institute of Peace. https://www.usip.org/sites/default/files/ resources/SR236Venhaus.pdf

Webber, D. \& Kruglanski, A. W. (2018). The social psychological makings of a terrorist. Current Opinion in Psychology, 19, 131-134. https://doi.org/10.1016/j.copsyc.2017.0 3.024 